Canadian University Music Review

Canadian University Music Review

Revue de musique des universités canadiennes

\title{
Subjectivity, Objectivity and Authenticity in Nineteenth-Century Bach Interpretation
}

\section{Glen Carruthers}

Volume 12, numéro 1, 1992

URI : https://id.erudit.org/iderudit/1014213ar

DOI : https://doi.org/10.7202/1014213ar

Aller au sommaire du numéro

Éditeur(s)

Canadian University Music Society / Société de musique des universités canadiennes

ISSN

0710-0353 (imprimé)

2291-2436 (numérique)

Découvrir la revue

Citer cet article

Carruthers, G. (1992). Subjectivity, Objectivity and Authenticity in

Nineteenth-Century Bach Interpretation. Canadian University Music Review /

Revue de musique des universités canadiennes, 12(1), 95-112.

https://doi.org/10.7202/1014213ar

All Rights Reserved (C Canadian University Music Society / Société de musique des universités canadiennes, 1991
Ce document est protégé par la loi sur le droit d'auteur. L'utilisation des services d'Érudit (y compris la reproduction) est assujettie à sa politique d'utilisation que vous pouvez consulter en ligne.

https://apropos.erudit.org/fr/usagers/politique-dutilisation/ 


\section{SUBJECTIVITY, OBJECTIVITY AND AUTHENTICITY IN NINETEENTH-CENTURY BACH INTERPRETATION}

\section{Glen Carruthers}

By the end of the Romantic Era there coexisted at least three discrete schools of Bach interpretation, each with a different notion concerning the sanctity of Bach's text: one school made frequent, extensive alterations to the Urtext; another blindly adhered to the letter of the score, giving little thought to its intrinsic value; and a third, arising late in the century, interpreted the music in accordance with what was then known of the performance conventions of the Baroque era. These schools could be called "subjective," "objective," and authentic," respectively.

The proponents of these schools did agree on one point, which was summed up by Spitta in his monumental Bach study of 1873-1880. Spitta affirmed that the ideal vehicle for Bach's keyboard music was not the harpsichord, clavichord or even the organ.

No instrument but one which should combine the volume of tone of the organ with the expressive quality of the clavichord, in due proportion, could be capable of reproducing the image which dwelt in the master's imagination when he composed for the clavier. Every one sees at once that the modern pianoforte is in fact such an instrument (Spitta 1951: II, 45).

In 1899 Oscar Bie concurred with Spitta that "all that Bach dreamed of, the pianoforte gave" (Bie 1966: 123). He went one step further, to suggest that Bach's keyboard music was revered in the nineteenth century because of the interpretive possibilities afforded by the piano. Only when played on the piano could the genius of Bach's works be fully appreciated. As Bie's editors explain, extrapolating from the author's original text:

When the instrument necessary to the full interpretation of Bach's claviermusic, the pianoforte, had arrived within measurable distance of perfection, then did Bach's own Art reach it highest formal expression, then once more did the fashion of things suffer a change, and his work began to take its place as a colossal monument ... . Wherever a pianoforte is found, there is [Bach's] temple (Bie 1966: 125). 
At the end of the century, most musicians, like Bie, were unwilling to cede to the harpsichord the piano's firmly entrenched position as the preferred medium for the performance of Bach's keyboard music. Nikisch, for example, conveyed his opinion to Landowska that the Chromatic Fantasy and Fugue was an aberration on the harpsichord (Landowska 1964: 354) and, well into our own century, Riemann maintained that the Well-Tempered Clavier could only be fully effective when played on the piano. ${ }^{1}$

Late nineteenth- and early twentieth-century musicologists like Spitta, historians like Bie, conductors like Nikisch and theorists like Riemann, to say nothing of the concert-going public, were in complete agreement on one fundamental issue of Bach Aufführungspraxis: the piano not only was appropriate, but was ideal for the performance of Bach's keyboard music. It is not at all surprising that this view prevailed. The notion that the piano was superior in every way to earlier keyboard instruments had gone virtually unchallenged for almost a century. It had been fostered by countless scholars, editors and performers, who were simply in accord with the tenor of their times in equating Bach's "clavier" with the modern piano.

Despite that the piano's unequivocal primacy in the nineteenth century stemmed from the Romantic conviction that "newer" is nearly always "better," it would be erroneous to assume that the nineteenth century engendered a single, preeminently pianistic manner of interpreting Bach's music. Even among musicians espousing the revisionist aesthetics of Romanticism, who advocated recasting Bach's music in a pianistic mold, there was little unanimity as to whether the Urtexte should be discreetly revised or completely rewritten. While an interest in stylistic interpretation and in fidelity, not to corrupt printed texts but to autograph and manuscript sources, gradually but substantially eroded a sentimental view of Bach which had caused performers, usually unwittingly, to distort the spirit and substance of his music, and while in some quarters "subjective" interpretation gave way to well intentioned but historically misinformed efforts to interpret Bach "objectively," it cannot be said that in the course of the nineteenth century "objectivity" ever eclipsed "subjectivity" or vice versa, or that "authenticity" posed a serious threat to the co-survival of the subjective/ objective status quo until about a decade ago.

The "subjective school," which was most typical of the Romantic Era, gave vent to a variety of artistic Darwinism that cannot be imagined in any other age. Performers, editors and even scholars were unwilling or unable to perceive Bach

${ }^{1}$ Das Klavier, auf welches das Wohltemperierte Klavier ... Anspruch machte, um voll zur Geltung zu kommen ..." (Hering 1949-50: 65). 
in the context of his own time and place. The Romantics reasoned that if Bach himself was not a Romantic, he certainly anticipated Romanticism and could best be understood from a Romantic and, in the case of the keyboard works, pianistic perspective. That Bach had assimilated many of the techniques of the Renaissance masters, had anticipated and even parodied the stile galant, and had influenced, at times profoundly, the Classicists through Beethoven, was of little importance. What mattered most was that Bach was relevant to the Romantic Age, that Romantic musicians understood Bach in a way that their precursors had not, and that Bach's influence on the nineteenth century was qualitatively and quantitatively greater than his influence on the late eighteenth century. Schumann's view is typical: "Mendelssohn, Bennet, Chopin, Hiller - in fact the whole [German] Romantic school is far nearer to Bach in its music than Mozart ever was; indeed, it has a thorough knowledge of Bach" (Schumann 1964: 93).

It is significant that the Romantics, who for the most part subscribed to an evolutionary theory of art and aesthetics, did not only consider it important that Bach had influenced Chopin, for example, but also that Chopin had been anticipated by Bach. Liszt stated that he heard much in a Bach prelude that resembled Chopin; he did not say that a Chopin prelude was sometimes reminiscent of Bach (Göllerich 1975: 44). Rubinstein discerned in the Goldberg Variations foreshadowings of the piano music of Cramer, Czerny, Hünten and Liszt; Rubinstein did not say that in the works of nineteenth-century composers he heard evidence of Bach's influence (Rubinstein n.d.: 17). There is more involved here than semantics. Liszt's and Rubinstein's statements affirm that what was at least as important to them, in the greater scheme of things, as the Romantics' affinity with Bach, was Bach's affinity with Romanticism.

By the end of the nineteenth century the identification of Bach with Romanticism was complete. An a-posteriori assessment of Bach's worth so coloured the Romantic perception of his music that nearly everyone heard presentiments of Romanticism in the Chromatic Fantasy and Fugue. ${ }^{2}$ In fact, some writers heard almost all of the Romantics in almost all of Bach's music. "A Michel Angelo does not include a Rembrandt, nor a Rembrandt a Monet; but in Bach there is a Beethoven, a Schumann, a Wagner" (Bie 1966: 93). The Toccata in D major (BWV 912) "is in content and technique Schumann all over" and the Prelude in E major (Well-Tempered Clavier, Bk. I) concludes "with a couple of bars in

\footnotetext{
${ }^{2}$ Landowska was one of the first to take exception to the Romantic notion that the Chromatic Fantasy and Fugue's true significance lay in its anticipation of Romanticism: "[If] we must see a happy message in the Chromatic Fantasy, it is not Beethoven, Chopin, or Schumann whom it heralded, but composers much newer to us because they are little known, such as Bach's precursors, Frescobaldi, Buxtehude, the lutenists, and others"' (Landowksa 1964: 49).
} 
Schumann's ingenious manner, still sweetly suggesting the spring-song of its earlier strains" (Bie 1966: 99, 113). "In no book is the future of music more clearly foretold [than in Bach's Partitas]. To see in the B flat major corrente, Chopin; in the B flat major gigue, Schumann; in the Cminor sinfonia, Beethoven; in the $\mathrm{C}$ minor Rondo and Capriccioso, Mendelssohn; ... is no mere enthusiastic fancy" (Bie 1966: 104). ${ }^{3}$

Since Bach's music was so resolutely Romantic, he could be claimed by the Romantics as one of their own. In some circles, this view persisted well past the turn of the century. In 1924, Herbert Westerby could write in all seriousness that "Bach's music, as a rule, is purely subjective and reflective in tone ... the language of a poet and a recluse" (Westerby 1971:45). In order to understand the emotional content of Bach's preludes and fugues, Westerby referred students to the programmatic titles assigned to them by "Carmen Sylvia, Queen of Roumania" (Figure 1).

Although Bie and Westerby represent an extreme position, their perceptions are nothing more than an inevitable consequence of the romanticization of Bach that had begun a century earlier, and had played a decisive role in the interpretation of his music throughout most of the Romantic Age. The Bach that Liszt, Rubinstein, Bie and Westerby identified so strongly with Romanticism was not the Bach of the clavichord, harpsichord or organ, but the Bach of the piano. And not only Bach transferred to the piano, but recast and adapted to accommodate the pianistic tastes and proclivities of the nineteenth century.

Although Field, Cramer, Moscheles, Clara Schumann and others included excerpts from the Well-Tempered Clavier in their concert repertoires before 1850 , audiences generally were not kindly disposed towards Bach's music. Clara Schumann's experiences were typical; when she played a Bach fugue at a salon in May 1832, her husband noted that her lack of success was explicable, since "the 'right people' were not present" (Litzmann 1979: I, 45). The view that only an elite were equipped to appreciate Bach was shared by Friedrich Wieck, who remarked that pianists who dared to play Bach in public should anticipate nearempty halls and a cool reception from those who were present (Litzmann 1979: $1,66)$. Clara herself wrote to Robert from Paris in 1839 that "no one will listen

\footnotetext{
${ }^{3}$ Bie alters the titles of the last two movements of the Partita in c minor (BWV 826), substituting the Italian rondo for the French rondeau and the noun capnriccio for the adjective canriccioso. Bach's titles thereby evoke Mendelssohn's Rondo Capnriccioso, op. 14, which reinforces Bie's point that Bach anticipates Mendelssohn.
} 
Figure 1: Examples of titles suggested by "Carmen Sylvia, Queen of Roumania" for Book I of the Well-Tempered Clavier. Reproduced from Westerby 1971: 45.

Prelude No. 2 (c)

Fugue No. 2

Prelude No. 3 (C-sharp)

Fugue No. 3

Prelude No. 4 (c-sharp)

Fugue No. 4

Prelude No. 5 (D)

Fugue No. 5

Prelude No. 9 (E)

Fugue No. 9

Prelude No.10 (e)

Fugue No. 10

Prelude No. 12 (f)

Fugue No. 12

Prelude No. 13 (F-sharp)

Fugue No. 13

Prelude No.17 (A-flat)

Fugue No. 17
The Pathfinder cheerfully going to his goal

We should (as Nietzsche says) dance through life

Harvest Festival with desolate Stubble Fields

The Village Dance, with Thought of Toil

Homesickness

Comfort to world-weary souls

Mountain Stream

Rustling of the Leaves

Lover's declaration

perhaps the response

Murmur of the Sea

Dialogue between Wind and Wave

Did I then ask to live?

I have borne the Burden of Fate

The Lily-of-the-Valley's Summons to a Fairy Banquet Love's Young Dream

The Knights of the Round Table

Sir Galahad

to Bach fugues here, not even the connoisseurs"(Litzmann 1979: I, 215). In 1841 she lamented that audiences were "taught to think more of virtuosity than of real music. A Bach fugue ... bores them" (Litzmann 1979: 1, 316). Forty years later the situation had not changed much, and Amy Fay is heard echoing Clara's sentiments:

In Tausig's and Kullak's conservatories I wasted quantities of time over things which are beautiful enough, and do to play to one's self, but which are not in the least effective to play to other people either in the parlour or in the concert-room - as Bach's Toccata in C, for example. Such things take a good while to learn, and are of no practical advantage afterward (Fay 1880: 318). 
To most audiences, Bach was only a resounding success on the piano when played in arrangements and transcriptions. ${ }^{4}$

But what of Bach's keyboard works that were widely appreciated by nineteenthcentury audiences? Let us examine, for a moment, the Chromatic Fantasy and Fugue, which the Romantics knew so well and with which they identified so closely. Mendelssohn, one of the most important early advocates of Bach's music and a conservative by the standards of his time, described his playing of the work in a letter to his sister dated 14 November 1840:

Yes! the arpeggios in the chromatic fantasia are certainly the chief effect. I take the liberty to play them with all possible crescendos, and pianos, and fortissimos, pedal of course, and to double the notes in the bass; further, to mark the small passing notes at the beginning of the arpeggios (the crotchets in the middle parts), etc., and likewise the principal notes of the melody just as they come: rendered thus, the succession of glorious harmonies produces an admirable effect on our rich-toned pianos (Mendelssohn 1863: 216). ${ }^{5}$

Half a century after Mendelssohn's death, Schirmer published Bülow's edition of the Chromatic Fantasy and Fugue. Bülow, like Mendelssohn, was not content to let the notes speak for themselves. He reasoned that a densely annotated and revised edition, which elucidated the Romantic ethos of the work, was long overdue. After all, it was in the Chromatic Fantasy and Fugue that "Romanti-

${ }^{4}$ Like many pianists, Clara did generate enthusiasm with arrangements of Bach's organ works. After her performance of an arrangement of the Organ Prelude and Fugue in e minor (BWV 533 or 548) in 1873, Clara confided to her diary that she "could never have believed [the work] would make such an impression on the public - but I was inspired as I seldom am by Bach when I play him in public, he puts such a tremendous strain on every faculty" (Litomann 1979: II, 295).

${ }^{5}$ Mendelssohn wrote out some examples and proudly stated that his playing of the work had been compared favourably with Thalberg's. Fanny was then advised to keep the contents of the letter to herself, so that the details of her brother's interpretation would remain a mystery. Another of Bach's keyboard works which Mendelssohn played frequently was the Triple Concerto in D minor, BWV 1063. He played the orchestral reduction for a performance by Moscheles, Clara Wieck, and Louis Rakemann (Leipzig, 1835), and took one of the solo parts in performances with Wieck and Rakemann (Leipzig, November 1835), Liszt and Hiller (Leipzig, 1840) and Moscheles and Thalberg (London, 1844). Charles Horsley (1822-1876) and Charles Salaman (1814-1901) have both left vivid accounts of the 1844 performance, which took place at the Hanover Square Rooms in London. In the finale (where no cadenza is called for), "Moscheles, a famous improvisatore, led off with a fine cadence [cadenza]. Thalberg followed with perhaps even more brilliant effect. Then Mendelssohn, who had been leaning listlessly over the back of his chair while the others were playing, quietly began his cadence, taking up the threads from the subjects of the Concerto; then, suddenly rousing himself, he would up with a wonderful shower of octaves, indescribable in effect, and never to be forgotten. The audience was so excited that the applause at the end was all for Mendelssohn" (Salaman 1901: 320). 
cism first entered the domain of pianoforte-literature." ${ }^{, 6}$ While applauding the accuracy of the Peters edition, ${ }^{7}$ Bülow acknowledged the need "to further perfect an interpretation of Bach's conceptions wherein the technical is blended with the spiritual." To this end, Bülow discarded the "stilts of "scholarly interpretation" " in favour of "emotional eloquence, confident of its effect." He also aimed "to exhibit the psychological, internal unity of the Fantasy and Fugue." He required that the Fugue be played attacca, "in an extremely tranquil style, as if of subdued mourning, with a gradual intensification up to the close (carefully avoiding undue haste), both in tempo and in forcefulness ...."

For this mode of interpretation [Bülow] had in mind, as a model, Mendelssohn's wonderful E-minor fugue, a faithful rendering of which and the master marked the shading so carefully that no mistake is possible - will have a retroactive effect as a pattern-performance in the lofty fuguestyle. With reference to his modifications in the phrasing, the editor feels that he has acted entirely without subjective arbitrariness; corrections of the fingering are based on the technical advances made in modern pianoplaying. The doubling of passages and amplifying of chords appeared necessary to enhance the coloring; it seemed more Bach-like to lend the fantasia something of the organ-tone, than to belittle it by an imitation of a spinet or clavichord. Liszt's imposing transcriptions of Bach's Organfugues afford, in this respect, perhaps the most instructive study for him who would penetrate the greatest composer of the future, whose real efficiency only began a century after his death .... The editor willingly assumes the responsibility for certain liberties, in taking which he has been led by a reverence of quite a different nature from the letter-worship of antiquarian sticklers for literalness, whose adoration is sometimes extended to misprints (Bülow 1896: preface).

I have quoted extensively from Bülow's preface since so many of his points are relevant to the present discussion; Mendelssohn is a useful model in formulating

${ }^{6}$ All quotations in this paragraph are taken from Bülow 1896: Preface.

${ }^{7}$ Clara Schumann played from the Peters edition to which Bülow refers. The Emilie and Karl Riemenschneider Memorial Bach Library at Baldwin-Wallace College houses an extensively annotated copy of this edition, which has formerly the property of Clara Schumann. It is evident that even she - a purist compared to most of her colleagues - could not resist tampering with Bach's text. In $\mathrm{m} .17$ of the Fugue, for example, she changed the alto $\mathrm{G}$ to an F-sharp to effect a complete change of harmony. At m. 48 she transposed the $E$ in the bass up an octave, thereby obscuring Bach's voiceleading. She did, however, refrain from the octave doublings so favoured by her colleagues, perhaps because Schumann had criticized her playing of a Bach fugue in 1840, noting that by doubling a passage in octaves "she had added a fifth voice incompatible with four-part writing" (Litzmann 1979: I, 315). 
an interpretation of Bach's fugues; attempts to imitate the harpsichord would subvert Bach's true intentions; Liszt's transcriptions provide the best clue to Bach's style; and, perhaps most significantly, Bülow is at odds with a Bach tradition that aims at a literal or "objective" interpretation of the score. ${ }^{8}$

It is likely that the piano editions published in the first quarter of the nineteenth century were responsible for fostering, if not originating, "objectivity" in the interpretation of Bach's music. Simrock, Nägeli, Hofmeister \& Kühnel and other early publishers of the Well-Tempered Clavier faithfully reproduced the manuscript sources with few editorial intrusions. That the manuscripts themselves were often unreliable does not alter the fact that publishers printed only what could be gleaned directly from the manuscripts.

Given the profusion of expression markings in Beethoven's sonatas or in the popular salon repertoire, Bach's works must have appeared stark and foreboding. Players, with little more to go on than the notes themselves, attempted nothing more than a "correct" reading of the text. There arose a strident and mechanical style of Bach interpretation that failed to do justice to the music or, for that matter, to fire the Romantic imagination. ${ }^{9}$ As Schweitzer points out, when certain editors "undertook to show the public again the living Bach [in the mid-nineteenth century], they had to fight a tradition that made stiffness, pedantry, and absence of temperament the true requisites for Bach playing" (Schweitzer 1962: I, 355). Editors from Czerny and Tausig, to Bülow, d'Albert

${ }^{8}$ Clara Schumann was predictably outraged by Bülow's Bach edition:

I have been trying to induce Hiller to write about Bülow's edition of Bach ... and to warn people against it. He so disfigures the works by his analyses that they are hardly recognizable, and he allows no grain of imagination or feeling to develop in his pupils. I have always forbidden my pupils to use these editions (Litzmann 1979: II, 364).

Liszt, conversely, used Bülow's editions for teaching purposes. Liszt was certainly one of the most ardent opponents of the "objective" Bach school. He urged one student not to play Bach in "too dry or too learned" a manner, and told another to avoid the "conservatory-style" of Bach playing which he so deplored (Göllerich 1975: 44, 50). Lachmund reports that Liszt's own performances avoided "the old-fashioned stiffness in rhythm" and "dryness in expression" that typified Bach playing; "on the contrary, considerable freedom was in evidence, so that the fugue flowed like a cadenza" (Lachmund 1970: 83). Incidentally, Jerger makes mention of a version of the Fantasy without the Fugue by Liszt (Göllerich 1975: 101), but it is not included in any catalogue of Liszt's works, nor is it mentioned in Friedrich Schnapp's "Verschollene Kompositionen Franz Liszts."

${ }^{9}$ When Donington cautioned in 1974 that what must be avoided above all is not so much overplaying, as underplaying in the guise of authenticity, he was describing a phenomenon that can be traced back directly to the nineteenth century (Donington 1974: 83). 
and Busoni took it upon themselves to provide interpretive suggestions, which, in the absence of autograph facsimiles, were frequently misconstrued as imperatives. These annotated editions were both the cause and effect of a new "subjectivity" in Bach interpretation (Example 1).

Czerny's Well-Tempered Clavier (C.F Peters: 1837) was the first edition of the work to feature detailed indications of dynamics, tempi, fingering, phrasing and pedalling. According to Czerny, his interpretation derived from a vivid recollection of Beethoven's Bach playing. Just how vivid Czerny's memory was, is a matter of conjecture. What is significant is that he even purported to rely on Beethoven, since Beethoven's Bach playing was probably both anachronistic and idiosyncratic. But Czerny aimed not to reproduce Bach's intentions faithfully, but to make Bach relevant to the 1840s. In this respect, and in his concern that Bach's music be made as "pianistic" as possible, Czerny established an important precedent. His edition became the model for many subsequent Bach editors, who were intent on supplying a burgeoning shoal of amateur players with performing editions of the "classical" repertoire.

Czerny altered Bach's ornamentation, changed accidentals, filled in some harmonies and thinned out others. He also suggested adding octaves to the bass line of the concluding measures of the Fugues in $\mathrm{c}$ minor and D major (Bk. I). ${ }^{10}$ It is important to recognize that, from a nineteenth-century standpoint, Czerny was simply exercising an editor's prerogative-some might have said obligation - to increase the pianistic efficacy of Bach's music. Czerny's interpretation was in no way inconsistent with the performance practices of many of the important musicians of his day. Moreover, Czerny's edition was welcomed as an antidote to the scourge of interpretive "objectivity." This is borne out by Schumann's review in the Neue Zeitschrift für Musik:

We approve, for the most part, of [Czerny's] tempo indications and also of his introductory remarks on the performance of the whole, as well as of his indications for the shading of each piece; the latter instructions we consider especially desirable, for nothing can be more tiresome or contrary to the meaning of Bach than to drone out his fugues or to restrict one's representation of his creations to a mere emphasis on the successive entries of the principal theme (Schumann 1964: 89).

${ }^{10}$ It is difficult to accept Bodky's thesis that these doublings demonstrate a vague understanding of the "Old Style," since Czerny does not elsewhere defer to conventions of Bach's time (Bodky 1960: 16). It is probable that Czerny meant only to increase the effectiveness of the cadence by underscoring the bass line. 


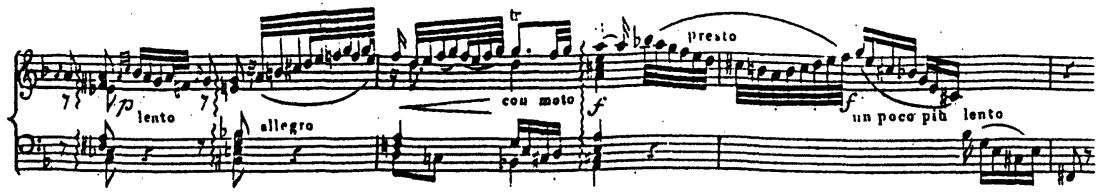

Example 1: Comparison of two nineteenth-century editions of the Chromatic Fantasy.

a) Chromatic Fantasy and Fugue, mm. 70-73. (Chromatische Fantasie für das Pianoforte. Neue Ausgabe mit einer Bezeichnung ihres wahren Vortrags, wie derselbe von J.S. Bach auf W. Friedemann Bach, von diesem auf Forkel and von Forkel auf seine Schüler gekommen. Leipzig: C.F. Peters [1819?].)

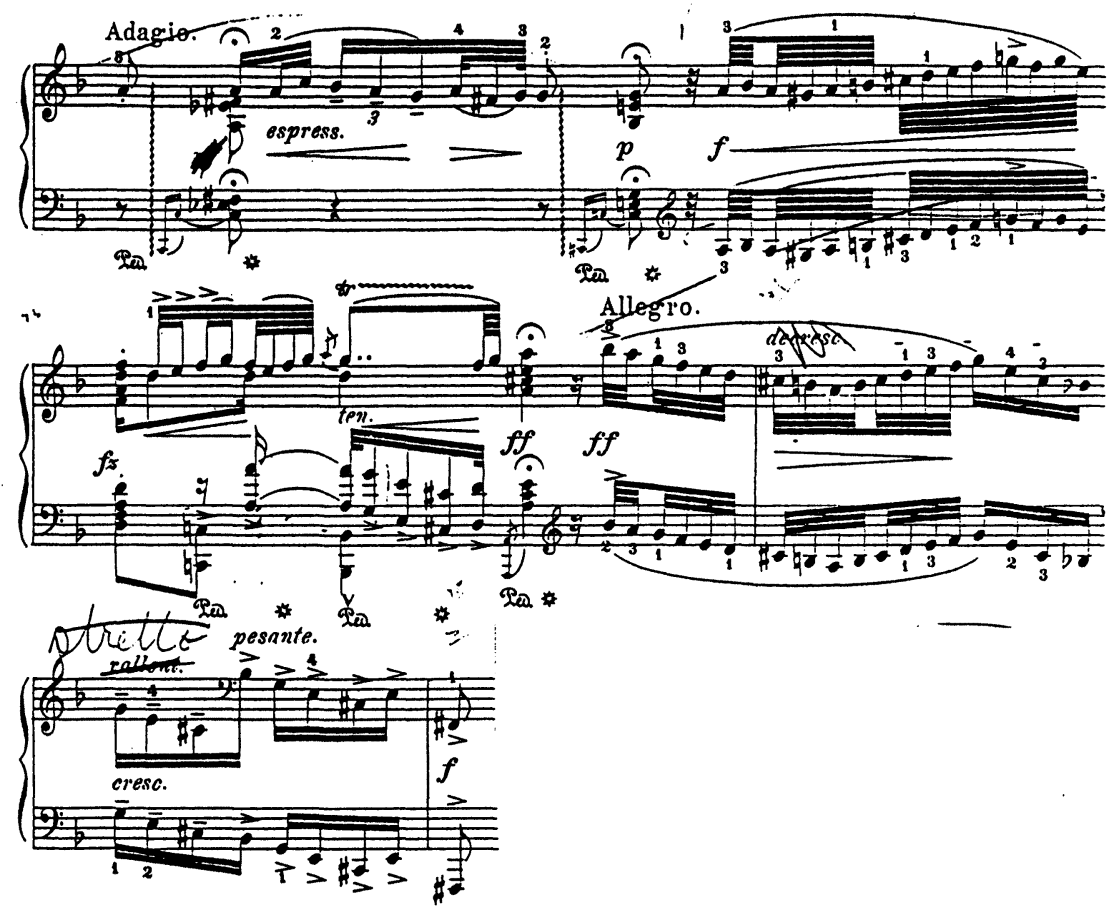

b) Chromatic Fantasy and Fugue, mm. 72-75. (Fantasia cromatica e Fuga edited by Hans von Bülow. New York: G. Schirmer, c1896.) 
Despite the widespread use of editions like Czerny's for both teaching and performing, and the public's thirst for Mendelssohn's brand of "revitalized" Bach, "subjectivity" was far from pervasive in the latter half of the nineteenth century. There had, inevitably, been a reaction to "subjectivity" that had taken the form of a powerful resurgence of "objectivity" in the 1840s.

A.B. Marx, in a series of articles for the Allgemeine musikalische Zeitung, was one of the first to decry the merits of the "new objectivity." He began with an article that appeared at the end of January, 1848, on the Chromatic Fantasy and Fugue. In it, he discredited the popular view that Bach was pious to a fault and that his personality was adversely reflected in his music. Bach was not the

"Old Master," walking about in a serious, upright and inexorable manner, with his grim smile, burning eyes and trim wig ... who sees a fugue in every measure ... and who forges an iron chain of chords and voices, so that no breath of feeling can possibly waft through ... . He was a true artist who carried in his heart the fullness of ... human life and poured it into his music" (Marx 1848: 33). ${ }^{11}$

Most significantly, Marx linked the "classical" conception of Bach as an archaic, stern and humourless Kapellmeister to contemporary practices in the performance of his music. With considerable irony, Marx noted that Bach

must be performed in the "classical" manner: purely, cleanly, solidly, strictly measured, every note as prescribed and, above all, calmly, very calmly. Anyone who wants to add "modern sentimentality" or "romantic ... fantasy," or to interpret as freely as a Beethoven might allow ..., would misunderstand the Master and "his style"; Yes, even vilify and deface him (Marx 1848: 33). ${ }^{12}$

Marx recognized that, although "classical objectivity" was undoubtedly a reaction against "romantic subjectivity," there was a middle ground that might more nearly approximate Bach's intentions.

11 ... ernsthaft gediegen unerbittlich einherschreitender Altmeister mit dem grimmlachelnden Gesicht und den brennenden Augen und der Stutzperiucke ... , die dem jeder Takt eine Fuge ... wird ... und ein Akkord an den andern, eine Stimme an die andere ehern geschmiedet ist, dass kein Hauch fessellosen Gemüths hindurchwehen kann .... Er war ein wirklicher Künstler, trug in seinem Herzen das ... volle ... Menschenleben und strömte dies in seinen Werken aus.

12 ... muss "klassisch" vorgetragen werden: rein, sauber, fest, strenggemessen, jede Note nach Vorschrift und vor Allem ruhig, ganz ruhig! Wer da "moderne Sentimentalität und "romantische ... Phantasterei" einrïhren wollte, oder nur so ungebunden agiren, wie ein Beethoven vielleicht erlaubt ... der würde den Meister und "seinen Style" missverstehen, ja entstellen und profaniren. 
Were the mind and soul in olden times radically different from our own? Had not Bach made his task to describe, and did he not surrender himself to ... feelings of joy, anger, pain, grief, and sadness with a deeply moved soul? It is not characteristic of profoundly stirred feeling that their undulations sometimes swell in rash and violent agitation and sometimes soften down to calm and quiet depths? Or do we want to escape from this eternal and true phenomenon because it is so often exaggerated in the wrong place (Levinskaya 1930: 243)?

The "new objectivity" nevertheless remained current for more than a halfcentury. Even Anton Rubinstein, whose understanding of Bach outstripped that of many nineteenth-century pianists, advocated a dry, uninflected reading of several excerpts from Book I of the Well-Tempered Clavier. During his lectures at the St. Petersburg Conservatory in the late 1880s, he noted that the first prelude should be "dry [and] loud, without any nuance until the end," that the second prelude "must be played without any shading, and [that] the second fugue ... can only be played with a hard, dry staccato " (Rubinstein n.d.: 12). ${ }^{13}$

The view that Bach's music was essentially inexpressive persisted, even in musically illustrious circles, past the turn of the century. As late as 1906, Eugen d'Albert cautioned that

there are many things in the art of Bach that are no longer congenial to us. I know there are people who can listen for hours to his cantatas without showing any apparent boredom. These people are either hypocrites or pedants. Bach knew nothing about the gradations of passions, of sorrow, of love, and he did not suspect the possibility of expressing them through music [sic] (Landowska 1964: 85).

D'Albert's response was not to join the "objectivists" and to underinterpret Bach in an effort to remain true to Baroque style, but to align himself with Bülow in dramatizing those works that could potentially speak to contemporary audiences. Whether or not d'Albert actually played from Bülow's edition of the Chromatic Fantasy and Fugue, he certainly captured its spirit. Konrad Wolff heard d'Albert perform the work in 1922 and attests that "his playing, impressive

13 ... trocken, laut, mit einem Ton jede "Nuance" bis zu Ende ... . Auch das zweite Präludium c-moll muss ohne alle Schattierungen gespielt werden, und die zweite Fuge ... kann nur mit einem schweren, trockenen Staccato ausgeführt werden. It should be remarked that the preludes cited here are more akin to etudes than most of the pieces in the Well-Tempered Clavier. Elsewhere Rubinstein speaks of the "melodious" and "tender" nature of the third prelude, the "depth" and "poetry" of the eighth fugue and so forth. What the "objectivists" believed was appropriate to the entirety of Bach's output, Rubinstein thought was applicable only to certain isolated works. 
as it was, could have been depicting the spread of an epidemic from the outbreak of an isolated case to a general bubonic plague" (Wolff 1983: 47).

At the turn of the twentieth century, one pianist in particular was determinedly championing Bach's cause. Busoni was intent on doing what Czerny had done in the 1830s, creating performing editions of Bach's works that could conceivably stem the tide of "objectivity." At the same time, Busoni aimed to provide a practical alternative to the excessive "subjectivity" of Bülow and d'Albert.

Busoni's versions of Bach's keyboard works, published between 1894 and 1923, bear considerable evidence of Czerny's influence. Busoni, like Czerny, does not preclude adding left-hand octaves at the end of the Fugue in c minor (Bk. I), but "agrees with Franz and Dresel ${ }^{14}$ in allowing them first to enter with the entrance of the theme, and also supports the opinion that this addition cannot be considered a violation of Bach's style"' (Busoni 1894: 7). Busoni also recommends adding a lower octave at the beginning of the c-minor Prelude (Bk. I), and suggests that it be sustained with the "third" pedal, like an organ point, through six full measures (in the original, the bass note is held for only one sixteenth-note beyond the first measure). Busoni defended himself against the claim that he was updating Bach's music, maintaining that he was merely repairing the damage that tradition had done. "By cleaning [these pieces] of the dust of tradition, I try to restore their youth, to present them as they sounded to people at the moment when they first sprang from the head and pen of the composer"(Dent 1933:110).

Busoni was, however, caught in the midst of a controversy that brought a whole new dimension to Bach interpretation. The revival of the harpsichord in the 1880 s challenged many of the tenets of both the "objective" and "subjective" Bach traditions, to some extent tempering the "subjectivists" and informing the "objectivists." At a time when the controversy concerning the piano's aptness as a medium for Bach's music did not "as yet occupy the public very seriously, as it [could] form no conception of the instruments Bach used," Schweitzer fuelled the debate by his endorsement of the harpsichord (Schweitzer 1962: I, 325). Most significantly, Wanda Landowska's concerts, recordings and fierce polemics were slowly giving the public a new perspective on Bach.

Although throughout the nineteenth century it had been universally accepted that the piano was an appropriate vehicle for the performance of Bach's music, the question whether or not it was worth attempting to approximate the timbre, dynamics and articulation of the harpsichord or clavichord arose only late in the

${ }^{14}$ Das wohltemperirte Klavier herausgegeben von Robert Franz and Otto Dresel (Leipzig \& Brussels, Breitkopf \& Härtel, c1890). 
century, when some scholars and performers recognized that Bach may have conceived his music specifically with Baroque instruments in mind. Earlier in the century this was not an issue, since it was assumed, without having been substantiated, that Bach must have been dissatisfied with the instruments at his disposal. Why, the Romantics would have asked, would one imitate instruments whose shortcomings were so obvious?

By 1900 pianists were inclined to assess the relative merits of the piano and harpsichord and to tailor their Bach performances accordingly. Rubinstein and Busoni, to take two of the most historically minded pianists of the time, were both dedicated to the promulgation of Bach's keyboard music, but were completely at odds concerning its "correct" interpretation.

Rubinstein was deeply engrossed in the still-nascent controversy concerning the aptness of the piano, in light of the reappearance of the harpsichord, as a medium for Bach's music, and was virtually alone in his generation in denying the superiority of the piano over the instruments of Bach's day. He believed that the sonorities of the harpsichord and clavichord were integral features of Bach's music that could not, despite the best intentions, be effectively replicated on the piano. Yet, despite his belief that pianists were at a disadvantage in baroque repertoire, he played Bach often, simulating the harpsichord's changes in registration and the clavichord's gradations of tone and dynamics by scrupulous attention to pedalling and articulation.

Busoni, too, was aware that the instruments of Bach's time possessed unique qualities. According to Dent, Busoni "knew too much [italics added] about the harpsichord to have any sentimental illusions about it" (Dent 1933: 259). Busoni, like Czerny before him, sought not to develop a pianistic style based on the capabilities of the harpsichord or clavichord, but to increase the pianistic efficacy of Bach's music by editing, arranging and transcribing it for piano. Accordingly, while Rubinstein's appraisal of the relative worth of the harpsichord on the one hand, and the piano on the other, ran counter to the current of nineteenth-century opinion, Busoni's ideas, at least in this one regard, were uncharacteristically quite typically "Romantic."

Of course, the re-emergence of the harpsichord brought more than the medium for the performance of Bach's music into question. While the "objective" school of the 1840s and 50s had purged Bach's music of Romantic accretions, it had offered only the most prosaic of alternatives. Renewed interest in the harpsichord, however, led performers to consider the manner in which Bach's music might have been played in his own day. Dolmetsch and Landowska, no matter how incongruous with their avowed aims their interpretive choices might now 
seem, not only paved the way for misguided efforts, in Taruskin's words, "to placate ol'debbil musicology," but also established the foundations of a sophisticated new school of Bach interpretation (Kenyon 1988: 144).

"Authenticity" initially waged a war on two fronts. The merits of both "subjectivity" and "objectivity" were called into question and, once again, Landowska played a leading role. Her disdain for "subjectivity," represented at one extreme by Bülow and at the other by Busoni, is well known. She had even less respect for "objectivity," whose practitioners, in her estimation, were "rarely scholars, but sciolists [for whom] the execution of the tiniest passage according to their own rules is dearer than all the beauties of art" (Landowska 1964: 95).

It remains to be mentioned that while Landowska's efforts, which had the support of E. Jacques Dalcroze ${ }^{15}$ and countless others, did much to curtail "subjectivity," they could not prevent and, in fact, partly occasioned a resurgence of "objectivity" in the 1920s. As Jörg Demus explains, "the excessively subjective ... Bach interpretation of many players from Czerny to Busoni ... was supplanted around the end of the First World War ... by a movement calling itself "modern objectivity." ... The ramifications of this movement ... extend to our own time (Demus 1954: 16). ${ }^{16}$

It is tempting to see in the history of Bach interpretation a continuum of cause and effect, whereby Czerny's reaction to the "objectivity" of his precursors engendered a counterreaction that manifest itself in a movement against "subjectivity." According to this theory, the "new objectivists" of whom Demus speaks could be viewed as a reaction against both the "subjectivity" of Busoni and the "authenticity" of Landowska. But it is not true that an ebb and flow of stylistic trends can be charted systematically from the eighteenth century to the present. Subjectivity and objectivity, freedom and constraint, innovation and tradition, have proceeded apace, sometimes crisscrossing and at times running parallel, throughout the entire history of Bach and the piano. At the turn of the twentieth century, however, for the first time "subjectivity" and "objectivity" could be renounced simultaneously, in deference to attempts to recover an "authentic" Bach style.

Whether or not historically informed performances approach historical "authenticity," or if "authenticity" merely constitutes a school no more or less valid $a$

15 Dalcroze 1908: passim.

${ }^{16}$ Die übertrieben subjektivierte ... Bachauffassung vieler Interpreten von Czerny bis Busoni wurde etwa nach Ende des ersten Weltkrieges, .... abgelöst durch eine sich "moderne Sachlichkeit" nennende Richtung. ... Die Ausläufer dieser Richtung ... reichen bis in unsere Zeit. 
priori than any other, will no doubt be debated for a long time to come. ${ }^{17}$ This is as it should be. There is, however, a danger inherent in the current convention that defines "historically informed" narrowly to mean "informed by history that is contemporaneous with a work's origin." Because this definition is so exclusive, and in the myopic belief that stylistic "authenticity" is the only valid interpretive goal, the rich performance traditions of the nineteenth century have recently received scant critical scrutiny. It is unfortunate that baroque performance practices were not bequeathed intact to succeeding generations and that speculation now necessarily serves in place of certainty. It would be equally regrettable if our links to nineteenth-century Bach performance traditions were irrevocably severed.

\section{REFERENCES}

BIE, OSCAR.

1966: A History of the Pianoforte and Pianoforte Players. Translated by E.E. Kellett and E.W. Naylor. Reprint of 1899 edition. New York: Da Capo Press.

BODKY, ERWIN.

1960: The Interpretation of Bach's Keyboard Works. Cambridge: Harvard University Press.

BULOW, HANS von.

1896: "Preface," Bach: Chromatic Fantasy and Fugue (Schirmer's Library of Musical Classics, vol. 22). New York: G. Schirmer.

\section{BUSONI, FERRUCCIO.}

1894: Eight Preludes and Fugues from Johann Sebastian Bach's Well-Tempered Clavichord [sic], vol. 1, revised and annotated by Ferruccio Busoni. New York: G. Schirmer.

\section{DALCROZE, E. JACQUES.}

1908: "Causerie Musicale: La Trrradition [sic]," Bulletin Française de la Société Internationale de Musique, IV/6, 655-661.

DEMUS, JORG.

1954: "Bach am Klavier," Oesterreichische Musikzeitschrift, IX, 7-17.

DENT, EDWARD J.

1933: Ferruccio Busoni: A Biography. London: Oxford University Press.

17 Of the large number of books and articles on this topic to appear in recent years, Nicolas Kenyon's anthology Authenticity and Early Music is especially recommended (Kenyon 1988). 
DONINGTON, ROBERT.

1974: The Interpretation of Early Music. New Version. London: Faber and Faber.

FAY, AMY.

1880: Music-Study in Germany. From the Home Correspondence of Amy Fay. Chicago: Jansen, McClurg \& Company.

GOLLERICH, AUGUST.

1975: Franz Liszts Klavierunterricht von 1884-1886 darstellt an den Tagebuchaufzeichnungen von August Göllerich. Edited by Wilhelm Jerger. Regensburg: Gustav Basse Verlag.

HERING, HANS.

1949-50: "Die Dynamik in Joh. Seb. Bachs Klaviermusik,"Bach-Jahrbuch, XXXVIII, $65-80$.

KENYON, NICOLAS, ed.

1988: Authenticity and Early Music: A Symposium. Oxford: Oxford University Press.

LACHMUND, CARL V.

1970: Mein Leben mit Franz Liszt: Aus dem Tagebuch eines Liszt-Schülers. Eschwege: G.E. Schroeder.

LANDOWSKA, WANDA.

1964: Landowska on Music. Collected, edited and translated by Denise Restout. Assisted by Robert Hawkins. New York: Stein and Day.

LEVINSKAYA, MARIA.

1930: The Levinskaya System of Pianoforte Technique and Tone-Colour. London: J.M. Dent.

LITZMANN, BERTHOLD.

1979: Clara Schumann: An Artist's Life. Translated and abridged from the fourth edition by Grace E. Hadow. Reprint of 1913 edition. 2 vols. New York: Da Capo Press.

MARX, ADOLPH B.

1848: "Seb. Bachs chromatische Fantasie," Allgemeine musikalische Zeitung, L/3, $33-41$.

MENDELSSOHN BARTHOLDY, FELIX.

1863: Letters of Felix Mendelssohn Bartholdy from 1833 to 1847. Edited by Paul and Dr. Carl Mendelssohn Bartholdy. Translated by Lady Wallace. London: Longman, Green, Longman, Roberts, and Green.

RUBINSTEIN, ANTON.

n.d. [lectures given 1888-1889]:Die Meisterdes Klaviers: Musikalische Vorträge 
über die Entwicklung der Klavier-Komposition. Translated from the Russian by M. Bessmertny. Berlin: Harmonie [Verlagsgesellschaft für Literatur und Kunst].

\section{SALAMAN, CHARLES.}

1901: "Pianists of the Past. Personal Recollections by the late Charles Salaman," Blackwood's Edinburgh Magazine, CLXX/1031, 307-330.

SCHNAPP, FRIEDRICH.

1942: "Verschollene Kompositionen Franz Liszts," Von Deutscher Tonkunst: Festschrift für Peter Raabe. Leipzig: C.F Peters.

SCHUMANN, ROBERT.

1964: On Music and Musicians. Edited by Konrad Wolff. Translated by Paul Rosenfeld. New York: McGraw Hill.

SCHWEITZER, ALBERT.

1962: J.S. Bach. Translated by Ernest Newman. Reprint of 1911 edition. Boston: Bruce Humphries.

SPITTA, PHILIPP.

1951: Johann Sebastian Bach. Translated by Clara Bell and J.A. Fuller Maitland. Reprint of 1889 edition. New York: Dover Publications Inc.

WESTERBY, HERBERT.

1971: The History of Pianoforte Music. Reprint of 1924 edition. New York: Da Capo Press.

WOLFF, KONRAD.

1983: Masters of the Keyboard: Individual Style Elements in the Piano Music of Bach, Haydn, Mozart, Beethoven and Schubert. Bloomington: Indiana University Press. 